\title{
Android Based Adventure Games to Enhance Vocational High School Students' Critical Thinking Skills
}

\author{
Sri Widi Lestari', Leo Agung ${ }^{2}$, and Akhmad Arif Musadad ${ }^{3}$ \\ \{widilestari92@student.uns.ac.id ${ }^{1}$, leo@staff.uns.ac.id², arifmusadad@staff.uns.ac.id ${ }^{3}$ \} \\ ${ }^{1,2,3}$ Universitas Sebelas Maret, Surakarta, Indonesia
}

\begin{abstract}
The development of technology spread widely to many other sectors, one of them is education. In this competitive 21 st century, education is developed integrated with technology. This article aimed to find whether or not using android based game puzzle adventure learning media can enhance students' critical thinking skill. The method used in this article is previous study through literature study stage and field study. In general, the whole learning process that happened in the class had not been supported by some interesting and innovative medias. The students used to accept the explanation from their teacher, so that they could not enhance their critical thinking skill in optimum way. One of innovations in learning media to enhance students' critical thinking skill is by using android based game puzzle adventure. This educational game can stimulate and train the students to solve their problems and cases through game play which full of adventure and puzzle. If the students are enthusiastic and meticulous in joining the lesson to solve problems in some questions, for sure it would strengthen their critical thinking skill. Therefore, it would help the students in enhancing their critical thinking skill.
\end{abstract}

Keywords: education, game puzzle adventure, critical thinking skill

\section{INTRODUCTION}

To compete in a 21 st century which is full of dynamic global competition, Indonesia should improve the quality of its human resources. Education in 21 st century is an integrative design, both from students' internal side and education system to build and redesign the public education including the whole components which involve in simultaneous education[1]. Nowadays, Indonesia use Curriculum 2013 (K13), the curriculum explains that the learning process for students should be integrated with 21 st century skill (4C: critical thinking and problem solving, creative, collaborative, and communicative) and HOTs (High Order Thinking skills). Based on the Decree of Minister of Education and Culture number 21 in the year 2016, it is also stated that students must have action and thinking skill including: creative, productive, critical, dependent, collaborative, effective, problem solver, and communicative. All of these aspects are the components that support each other to create skillful humankind in 21 st century $[2]$.

Based on a survey held by Organization of Economic Co-operation and Development (OECD), it showed that the result of Programme for International Student Assessment (PISA) in 2015, Indonesia is on 403rd place [3]. The lower position owned by a country in PISA, it can 
indicate that Indonesian students' skill in answering questions related to critical thinking skill are still low [4].

Critical thinking skill is a part of higher thinking skill which is useful to anticipate and solve any kinds of complicated problems and insist on decision-making with deep analysis. If someone has critical thinking skill, he or she is expected to be able to adapt and ready to deal with various challenges in the present or future. Thinking skill should be trained since in childhood, because everyone has different thinking skill from one to each other. Thinking skill reflects human's behavior in larger process scale to decide about what should be decided or should not be decided. Critical thinking, the ability to analyze a problem using data and various strategies, is a skill that can be improved in students and can improve with experience and practice [5]. To deal with the more complicated problems, a person will need thinking activity or knowledge pattern which is innovative and integrated each other, so that the problems faced would be more substantive [6].

Learning media is a means used by teacher to deliver a message contained in learning sources to students. This aimed to make students feel enthusiastic to join the learning process. Learning media is beneficial to display the object or event related to learning material, it is used to make the ongoing learning material or topic to be more attractive, interactive, and also improve the role of teacher and students in more positive way, so it can enhance the quality of learning. One of learning media that can be used in the present is game media as an education strategy media to attract students' attention in order to be more enthusiastic in learning[7]. By combining mobile technology (smartphone) with game, it can enhance students' academic skill[8]. The use of learning media game that can attract students' enthusiasm are be able to make deeper impression and still remain to focus on the goal that want to be achieved in the learning process [9].

Based on the result of a survey held by Fish Game Stats Database of America (2014) showed that $27 \%$ gamers are dominated by children in school age (under 18 years old) [10]. The development of media game that suitable with the current needs is expected to support the teaching learning process and attract students' interest and learning motivation. Based on the result of a survey held by monkey survey intelligence toward mobile device users (android) in United State of America (USA) on July 2016, it can be found that genre game; adventure and puzzle is on top 3 rank of the most commonly used game by active game mobile users [11].

The application of smartphone technology based learning combined with games has been proven can increase students' motivation in learning. However, thing that must be a concern is the use of cellular technology, the type of game, which is also must be adjusted to the learning strategy and class needs, especially from the students themselves. The use of game learning media that attracts students' enthusiasm for sure will also leave a deeper impression and can create a more pleasing learning environment conditions while they keep on paying attention to the goals that wanted to be achieved in the learning [9]. Based on the results of research studies on the impact of the game, it is known that games have a positive impact in improving students' learning achievement [12] and can improve students' critical thinking skills [13].

Based on the results of the various literature studies above, this study will develop accounting learning media in the form of android-based adventure games to improve students' critical thinking skills toward students of SMK N 1 Juwiring. By using learning media in the form of game, the students are expected to be more enthusiastic in joining the lesson, so that it will improve their critical thinking skills. 


\section{METHOD}

The method of writing this article is based on the result of the previous study including literature study and field study. The subject of this research is eleventh grade students of Accounting in SMK N 1 Juwiring. The technique of collecting data is carried out by conducting interview and observation. The technique of validity test is carried out by using triangulation technique, to test the validity of data to the same source by using different technique. The technique of data analysis is adjusted with the characteristic of data gained by the researcher, for qualitative data will be analyzed systematically by using descriptive qualitative technique. Meanwhile, quantitative data will be analyzed by using descriptive percentage.The field study was conducted at SMK N 1 Juwiring to find out the learning activities that occurred. The technique of data analysis uses descriptive techniques. Observation data are obtained through observation sheets in the form of numbers that will be calculated in percentages. The data that have been presented in the form of percentage then will be analyzed into qualitative sentences, so this technique is called as qualitative descriptive with percentage. Qualitative data were analyzed systematically, regularly and structurally in order to have stage meanings in descriptive analysis including: data collection, data reduction, data display, and verification or conclusion [14].

\section{RESULT AND DISCUSSION}

This article used data from the result of previous study which involve literature study and field study. Based on the result of field study which is conducted in eleventh grade class of Accounting in SMK N 1 Juwiring, it can be found that during the lesson, the teacher only use whiteboard and power point as the media. The teachers have limitations using innovative learning media, especially one that based on latest technology. The learning media of taxation subject is not innovative, the source of learning material is not up to date, the students' critical thinking is still low, and school facilities do not support the teaching learning activity.

During the lesson, if the teacher presents questions, the students are not brave enough to deliver their opinion. The students also find difficulties in finding and solving the problems. The students find difficulties in understanding the material since they only receive the concept of the material (do not feel skeptical). When the teacher presents some questions in the form of exercises, so far the students still have difficulties in analyzing the questions. The monotonous learning activities that do not implement interactive communication among the students will make students feel bored easily, the students are not too enthusiastic in delivering their idea. This learning activity will pursue the students in enhancing their thinking, particularly critical thinking skill. The data of students' critical thinking skill is collected by doing observation using sheet observation instrument. The following are the result of students' critical thinking skill which is displayed on table 1:

Table 1. The Data of Critical Thinking Skill Observation Result

\begin{tabular}{lccc}
\hline \multicolumn{1}{c}{ Description } & Explanation & Interpretation & Analysis \\
\hline $\begin{array}{l}\text { The students that pass the } \\
\text { indicator }\end{array}$ & 10 students $(20 \%)$ & 5 students $(10 \%)$ & 10 students $(20 \%)$ \\
\hline $\begin{array}{l}\text { The students that do not } \\
\text { pass the indicator }\end{array}$ & 40 students $(80 \%)$ & 45 students $(90 \%)$ & 40 students (80\%) \\
\hline
\end{tabular}

(Source: Primary data, 2018) 
During the observation was ongoing, it can be found if the teacher gave questions, the students were not confident to explain their ideas because they did not have basic theory or strong proof to answer the teacher's questions (explanation). From 50 students, only 10 students $(20 \%)$ could complete the activity in the explanation indicator. Meanwhile, 40 students $(80 \%)$ still did not complete their activity in this indicator. The students have difficulties in understanding the material (interpretation). From 50 students, only 5 students $(10 \%)$ could complete the activity in the interpretation indicator. Meanwhile, 45 students $(95 \%)$ still did not complete their activity in this indicator. It was caused by the condition where the students only receive the concept of the material. When the teacher gave questions, the students still have difficulties in analyzing the problem in the questions given to them (analysis). From 50 students, only 10 students $(20 \%)$ could completed the activity in the analysis indicator. Meanwhile, 40 students $(80 \%)$ still did not complete their activity in this indicator.

According to the problems that happened in the class, it indicates that students' critical thinking skill is still low. The phenomenon of those problems is caused by the inability of the teachers in using supporting digital media that help them to ease the learning activity. In fact, the learning enthusiasm owned by the students can be improved by using more innovative learning media, so that they are interested to join the teaching learning process.

One way to make active learning is through the development of more innovative learning media [15]. Learning media that can be utilized at this time is one of them is game media that can be used as an educational media strategy to attract the attention of children to be more enthusiastic about learning [7]. Learning activities in the classroom must be made fun, so that students are interested and enthusiastic to learn, so they can achieve the learning goals that have been planned at the beginning. Educational games are innovative learning media that can be used by teachers as a medium to increase student learning enthusiasm in the classroom. The learning atmosphere that cannot actively foster student interaction makes learning less meaningful, because students are not involved in learning through real experience. If students are interested and involved in interactive communication in the classroom, simultaneously students' critical thinking skills can also increase.

Game in the Android-based puzzle adventure genre are a learning media that can be operated via a smartphone. This educational game with the Android-based puzzle and adventure genre is suitable for improving critical thinking skills because: 1) makes it easier for students to solve problems in doing practice questions [16], 2) making the learning process more interactive [15], 3) making the learning process more interesting as well as easier-to-understand material [9], 4) helping to prove concepts into real application or role applications [17], 5) making students more interested in participating in games full of challenges, missions, problems and puzzles [18 ]. Through the use of interesting learning media, it will certainly make students more enthusiastic to participate in learning activities, because students feel interested in delivering more innovative and fun material. The development of Android-based game learning media is also based on the current environment, where the majority of students already have and use android in their daily activities.

There are plenty of researches conducted to develop media in learning process; each research certainly has its own characteristics and advantages, such as the type of the media being developed, or variables that will be improved. The development of learning media involving game elements in learning with collaborative game genres has not been widely studied in previous studies

A research conducted by J, Raiyn [19] entitled "Toward Development Game-Based Adaptive Learning" developed a digital game based on adaptive learning to improve students' high-level thinking skills. The difference between this research and J's research, Raiyn is the 
game developed by J, Raiyn is based on personal computer (PC) while the game development in this research is based on Android (smart phone). This research combines two game genres, while J's research, Raiyn does not specifically explain the genre of games that has been developed. J's research, Raiyn reviews the effectiveness of digital games on high-level thinking skills in general, while this study focuses on the study of critical thinking skills by measuring critical thinking skills in more detail through several indicators.

A research conducted by S, Mohammad [20] entitled "The Effect of Computer Games on Students' Critical Thinking Disposition and Educational Achievement" developed computerbased games with adventure genres to improve critical thinking skills and learning achievement [21]. The difference between this research and Mohammad'S research, is that this study combines two game genres, namely adventure and puzzle with the aim of making the game more interesting. Games that has been developed in this study are based on Android Operating System because Android is more commonly used in this geographical region.

\section{CONCLUSION}

Based on the result of previous study that have been conducted, it can be concluded that education has to become more dynamic as well as the needs of the current era. Education must be more developed innovatively, one of the ways is through interesting learning media. Game within puzzle generate considered suitable choices because they got high interest from the users, especially teenagers. Adventure games can stimulate students to be more active and enthusiastic in joining the lesson in class. The students' enthusiasm is triggered to solve the problems and cases through game play that are full of adventures and puzzles. If the students are enthusiastic in joining the lesson, it will stimulate their critical thinking in order to be active and trained. Therefore, it helps students to develop their critical thinking skill. Finally, the development of adventure games media is expected to enhance students' critical thinking skill in the optimal way.

\section{REFERENCES}

[1] K. Kay, "Twenty-First Century Students Need 21st Century Skills. Bringing Schools into the 21st Century," Explor. Educ. J. Purp., pp. 41-65, 2011.

[2] Kementerian Pendidikan dan Kebudayaan, Permendikbud Nomor 21 Tahun 2016 Tentang Standar Penilaian Pendididikan. 2016.

[3] Organisation of Economic CO-operation and Development (OECD), "PISA (Programme for International Assessment) 2015," 2018.

[4] D. Irawan, "Analisis Kemampuan Berpikir Kreatif Matematis Melalui Pembelajaran Model 4K Ditinjau dari Gaya Belajar Siswa Kelas VII,” Universitas Negeri Semarang, 2015.

[5] A. Fisher, Berpikir Kritis (Sebuah Pengantar). Jakarta: Erlangga, 2009.

[6] G. Tsaparlis and U. Zoller, "Evaluation Of Higher Vs. Lower-Order Cognitive SkillsType Examinations In Chemistry: Implications For University In-Class Assessment And Examinations," R. Soc. Chem. J., vol. 7, no. 2, pp. 37-63, 2003.

[7] Z. Okan, "Edutainment: is Learning at Risk?," Br. J. Educ. Technol., vol. 34, no. 3, pp. 255-265, 2003.

[8] C.-H. Su and C.-H. Cheng, "A Mobile Game-based Insect Learning System for Improving the Learning Achievements," Procedia - Soc. Behav. Sci., vol. 103, no. 13, pp. 42-50, 2013. 
[9] R. R. Noviami and W. Christijanti, "Pengembangan Media Digital Game Based Learning (DGBL) Pada Pembelajaran Sistem Reproduksi Manusia Di Sekolah Menengah Pertama (SMP)," Unnes J. Biol. Educ., vol. 1, no. 3, pp. 203-210, 2012.

[10] Big Fish, "Most Popular Mobile Game Genres," Big Fish Inc., 2014. [Online]. Available: https://www.bigfishgames.com/blog/stats/the-average-gamer-then-and-now/.

[11] I. Kurniawan, "Game Arcade Paling Diminati Pengguna Smartphone, Game Edukasi Tidak Populer," TECHINASIA, 2016. [Online]. Available: https://id.techinasia.com/insight-dari-surveymonkey-tentang-genre-game-mobileterlaris.

[12] C. C. Yi and G. Hwang, "Trends in digital game-based learning in the mobile era : a systematic review of journal publications from 2007 to 2016 Trends in digital gamebased learning in the mobile era : a systematic review of journal publications from 2007 to 2016 Ching-Yi Chang," Int. J. Mob. Learn. Organ., vol. 13, no. 1, pp. 68-90, 2019.

[13] R. Marzano J, "Using Games to Enhance Student Achievement," Meeting Students Where They Are," Educational Leadership, 2010. [Online]. Available: http://www.ascd.org/publications/educational-leadership/feb10/vol67/num05/UsingGames-to-Enhance-Student-Achievement.aspx. [Accessed: 21-Oct-2018].

[14] L. J. Moleong, Metode Penelitian Kualitatif. Bandung: PT. Remaja Rosdakaraya, 2014.

[15] A. Arsyad, Media Pembelajaran. Jakarta: Raja Grafindo Persada, 2013.

[16] S. D. Mcdonald, "E Nhanced C Ritical T Hinking S Kills Through P Roblem -S Olving G Ames In S Econdary S Chools," vol. 13, pp. 79-96, 2017.

[17] Sadiman, Media Pendidikan: Pengertian, Pengembangan, dan Pemanfaatannya. Jakarta: Rajawali Pers, 2014.

[18] L. Pannese and M. Carlesi, "Games and Learning Come Together to Maximize Effectiveness: The challenge of Bridging the Gap," Br. J. Educ. Technol., vol. 38, no. 3, pp. 438-454, 2007.

[19] J. Raiyn, “Toward Development Game-Based Adaptive Learning," J. Educ. Pract., vol. 8, no. 28, pp. 104-112, 2017.

[20] M. Seifi, "The Effect of Computer Games on Students' Critical Thinking Disposition and Educational Achievement," Int. J. Educ. Lit. Stud., vol. 3, no. 4, 2015.

[21] K. Saddhono and M. Rohmadi, "A Sociolinguistics Study on the Use of the Javanese Language in the Learning Process in Primary Schools in Surakarta, Central Java, Indonesia." Int. Edu. Stu., vol. 7 no.6 pp 25-30, 2014 